\title{
COMPARISON OF TAX AMNESTY IMPLEMENTATION IN DEVELOPING COUNTRIES
}

\author{
(Comparison Study of Tax Amnesty Implementation between \\ Indonesia and India 2016)
}

\author{
N. Purnomolastu* \\ pur_nomolastu@yahoo.com
}

\section{Abstract}

Taxes are a major source of revenue in a large states so the governer strives in various ways to increase state revenues from taxes. This happened because not everyone who pays taxes, referred as taxpayers is willing to pay their taxes well and correctly. One of the ways used by the government is issuing a policy that can increase tax revenues. That policy is known as Tax Amnesty.There are many countries, both developed and developing countries that have implemented Tax Amnesty policy. In this paper, the author analyzes the implementation of Tax Amnesty by comparing two developing countries in Asia, Indonesia and India, This kind of study is known as comparative study. One of the considerations about the pointing of the countries as subjects is both of Indonesia and India started to implementing Tax Amnesty at the same time in 2016. The analysis is done by comparing the background, the purpose of the implementation, and the results obtained from Tax Amnesty policy. The result of Tax Amnesty showed that different implementation purpose, implementation period, and the way to implement caused different results of tax revenues.

Keywords : tax payer, tax amnesty.

\section{Introduction}

Taxes are the backbone of a state economics, which means that tax is the most dominant factor as state revenue, even though not every country in the world fully rely their revenues from taxes. Some Middle Eastern countries had their main source of revenues from oil fields. While in other part of the world had their main source of revenues from taxes. This is proven the different impositions of tax fare. For example, in Middle Eastern countries like Saudi Arabia, Kuwait, and Qatar, they had 0\% fare for income taxations, while some European countries like Denmark and Spain charge $55 \%$ and $52 \%$ respectively as their income tax fares. (https://www.halomoney.co.id/ blog/infografik-tarif-pajak-penghasilan-didunia). But the reality is, the country main revenue that sourced from taxes often not reaches the targeted results.

\footnotetext{
* Taxation Program of Politeknik Ubaya, Surabaya.
} 
There are some factors that caused the state revenues based from taxes are not accordance with the plan, one of those things is not every citizens that should be a taxpayer is willing to register themselves as a taxpayer. And the other factor is not every registered taxpayers are paid their taxes correctly according to the implemented policies.

Those things are the reasons why some countries starting to plan implementing many policies to increase their country revenues. The policies started from giving tax amnesty and continued by giving penalties such as material penalties or imprisonment by criminal penalties.

Although there are many penalties ahead for tax misappropriation, however it's not guarantying the taxpayers to obey the policies that issued or set by the government. The taxpayers and the government seems like they are competing each other to make tactics, while the taxpayers are looking way to minimize, on the other hand the government try to maximize the tax amount that should be paid. Hence, the government choose to impose a policy that called Tax Amnesty. Tax Amnesty was implemented in many countries, both developed or developing countries. Kluwer (2011:4) claimed that some developed countries has had Tax Amnesty, they are :

- European, such as Austria, Belgium, Denmark, Finland, France, German, England, Ireland, Italy, Netherland, Norway, Portugal, Russia, Swiss, and Sweden.

- Latin America, such as Argentina, Bolivia, Brazil, Chili, Colombia, Costa Rica, Ecuador, Honduras, Mexico, Panama, Peru, and Uruguay.

- Asia, such as India, Indonesia, Malaysia, Pakistan, Philippines, and Sri Lanka.

- Australia, such as Australia and New Zealand.

- Africa, such as South Africa.
It's interesting to analyze Tax Amnesty implementation in developing countries by comparing two countries that currently implementing Tax Amnesty in the same time, those are Indonesia and India. There are some considerations for choosing those countries, including :

- Both countries are developing countries in Asia.

- Both are started doing Tax Amnesty together in 2016

- Both are doing Tax Amnesty more than once

- Both have large population

Even though both countries have many similarities, but the final results are significantly different, so it's interesting to analyze what both countries have done.

\section{Research Purpose}

Comparing the implementation of Tax Amnesty in countries that done in 2016 at the same time, Indonesia and India.

\section{Research Benefit}

The aim of this research is analyze the effectiveness of Tax Amnesty that implemented by Indonesia and India that have different purpose and implementation procedures.

\section{Research Methods}

Data collecting is be done by library research, which sourced from journal, scientific works, seminar, other articles, and related taxation policies.

\section{TA Definitions}

Definition of Tax Amnesty in broader terms by Eric Le Borgne (2006)

"A Tax Amnesty can be defined as a program that provides for a reduction in real terms of taxpayers' declared or undeclared tax liabilities as established by law '”. 
While Baer Katherine ( 2008 ) stated,

"A limited- time over by the government to a specific group of tax payer to pay a defined amount, In exchange for forgiveness of a tax liability (including interest and penalty) Relating to a tax previous tax period (s), as well as freedom from legal

Tax Amnesty based on Undang- undang no 11 year 2016 art 1, defined :

Tax Amnesty is deletion of owed taxes, not charged with taxation administration penalties and taxation criminal penalties, by exposing the treasure and paid the ransom that regulated in this constitutions.

From both three definitions, we can have some core meaning that contained in Tax Amnesty, which are :

- The policies are committed to the ruler, in this term is the government

- Addressed to group of people, in this term is taxpayers

- Those policies are forgiveness of owed debt or obligation, which is termed as tax, while the penalty and interests are included in the forgiveness of tax liability

- Done over a period of time

\section{Types of Tax Amnesty}

There are many kind of Tax Amnesties that had been done by the worldwide government, depends on the main purpose of the program. Pellechio, 1993 (in Katrine Baer, 2008:9, Tax Amnesty, Theory, trends and some Alternative, International Monetary Fund); said there are some types of Tax Amnesty, which are (Table 1).

Based on the table above, we know that different target of Tax Amnesty can lead to different types of implemented Tax Amnesty and the time period given, such as an unregistered taxpayer is best suited tax amnesty is interests of income tax and balanced with enhancement of penalty and charged only once.

\section{Tax Amnesty Implementation in Some Countries}

Tax Amnesty had been done in some countries with many kind of purpose and results, those are shown in the table listed below (Table 2).

Based on table above, it shows that there are some kinds of Tax Amnesty purposes, they are: General Tax Amnesty in Ireland, which included every kind of taxes; Specific Tax Amnesty in Portugal and Italy, which included some kind of taxes such as income taxes (limited to income taxation), reparation of untaxed assets, and in India, that enable their taxpayer to exchange their unpaid taxes to government bonds (government bonds designed for untaxed income).

\section{The Purpose and Benefits of Tax Amnesty}

Every policies that been decided by the government always had its purpose and benefits, and the general purpose and benefits of Tax Amnesty implementation, suggested by Prastowo (2016) are :

- Increase the basic information about unpaid taxation and taxpayers' wealth

- Increase the state revenues from unpaid taxpayers taxes

- Enhance data access to financial constitutions, either national or internationally

- Restoration or Repatriation taxpayers' wealth which is still in overseas to be included in the nation economic systems.

In a book called Tax Policy and Economy (Herman, 1987), it said that there are some benefits in implementing tax amnesty, which are : 
- enhance the taxpayers obedience

- enhance information about registered or unregistered taxpayers

- enhance taxpayers awareness

- reduce taxpayers guilty feeling and worries about future penalties.

Meanwhile, based on UU no 11 year 2016, art 2 par 2 , benefits of Tax Amnesty are :

- Accelerate economic growth and restructuration through wealth, which will impacts to increase domestic liquidities, improvement of Rupiah exchange rates, lower interest rates, and increased investments.

- Encourage tax reformation towards fairer taxation systems, also expansion of basic taxation data which more valid, comprehensives, and integrated; and

- Increase tax revenues that will be used to finance development

\section{Analysis Results}

\section{Demographical Factors}

\section{Population}

The bigger total population of a country, the bigger their domestic income will be.
The domestic income of a country is termed Gross Domestic Product (GDP).

\section{Indonesia}

Indonesia is South East Asia biggest country with their 2015's total population is 257 million $(3,45 \%$ of people in the world), and ranked four in total population in the world by 2017 .

\section{India}

India is South Asia with biggest population in the area, in fact India is the runner up of most populated country in the world. Their total population is 1,3 billion by 2017 .

\section{Tax Ratio}

Is proportion of total gross income from a country, compared to its paid taxes. The bigger tax ratio shows more obedience of a country taxpayer to fulfill their taxation obligations.

\section{Indonesia}

Indonesia has 257 million people in 2017 with their GDP in 2015 is about 861,9 million USD or 3,346.49 USD per capita. Compared with the paid taxes, Indonesia's tax ratio is $12 \%$ while their economic growth in 2016 is $5,02 \%$.

\section{India}

India's 2017 total population is 1.300

Table 1. Possible Design Features of Tax Amnesties

\begin{tabular}{|c|c|c|c|c|}
\hline Who Is Targeted & $\begin{array}{c}\text { What Tases Are } \\
\text { Covered }\end{array}$ & $\begin{array}{l}\text { What Is } \\
\text { Forgiven }\end{array}$ & Accompanied by & Other \\
\hline $\begin{array}{l}\text { Unregistered taxpayers } \\
\text { Nonfilers }\end{array}$ & $\begin{array}{l}\text { Personal taxes } \\
\text { Business taxes }\end{array}$ & $\begin{array}{l}\text { Interest } \\
\text { Tax penalties }\end{array}$ & $\begin{array}{l}\text { Increased } \\
\text { enforcement }\end{array}$ & $\begin{array}{l}\text { Duration } \\
\text { - One-time } \\
\text { - Permanent }\end{array}$ \\
\hline $\begin{array}{l}\text { Delinquent taxpayers: } \\
\text { - Unpaid tax liabilities } \\
\text { Evaders: } \\
\text { - Nonreported tax } \\
\text { liabilities } \\
\text { - Underreported tax } \\
\text { liabilities }\end{array}$ & $\begin{array}{l}\text { Property taxes } \\
\text { Other }\end{array}$ & $\begin{array}{l}\text { Criminal } \\
\text { prosecution: } \\
\text { - Civil penalies } \\
\text { - Imprisonment } \\
\text { Tax liabilities: } \\
\text { - Small amounts } \\
\text { - Anv amount }\end{array}$ & $\begin{array}{l}\text { Tax reform: } \\
\text { - General } \\
\text { - Designed, in part, } \\
\text { to address non- } \\
\text { compliance }\end{array}$ & $\begin{array}{l}\text { Basis: } \\
\text { - Legislative } \\
\text { - Administrative } \\
\text { decree }\end{array}$ \\
\hline
\end{tabular}


million, while their GDP in 2015 is 2,074 trillion USD, means their per capita income is 1,581.59 USD. Based on this situation, it can be concluded that India's tax ratio is $17 \%$ while their economic growth in 2016 is $7,1 \%$.

\section{Implementation of Tax Amnesty Types and Objectives of Tax Amnesty}

Remember that there are many kinds of Tax Amnesty, and each Tax Amnesty has different objectives. General Tax Amnesty's objective is forgiveness of any kind of taxes, while Specific Tax Amnesty is based on its

Table 2. Tax Amnesty in some countries

\begin{tabular}{|c|c|c|c|c|}
\hline Country & Amnesty Year & form/main taxes covered & Collection (\$ Mio.) & $\%$ of the tax rev. \\
\hline Argentina & 1987 & $\begin{array}{l}\text { previously unreported income for } \\
\text { investment purpose }\end{array}$ & virtually no revenue & \\
\hline Argentina & 1995 & General Tax Amnesty & 3,900 & \\
\hline Australia & $\begin{array}{l}\text { Twice during } \\
80 \text { s }\end{array}$ & $\begin{array}{l}\text { Participants in specific avoidance } \\
\text { scheme, persons not lodging returns }\end{array}$ & & \\
\hline Austria & 1982 & All tax claims prior to 1979 & poor results & \\
\hline Austria & 1993 & $\begin{array}{l}\text { special program to encourage } \\
\text { repatriation of untaxed assets }\end{array}$ & $\begin{array}{l}\text { increase of the tax base } \\
\text { (around } 58 \text { percent) }\end{array}$ & \\
\hline Belgium & $1984 / 1985$ & $\begin{array}{l}\text { Income exempted from tax if } \\
\text { invested (e.g., government bonds) }\end{array}$ & poor results & \\
\hline Colombia & 1987 & $\begin{array}{l}\text { report previously unreported assets } \\
\text { or over-reported liabilities }\end{array}$ & 100 & $\begin{array}{l}0.3 \% \text { of gross } \\
\text { domestic } \\
\text { product }\end{array}$ \\
\hline Finland & 1982/1984 & Surplus Interest Affairs & & \\
\hline France & 1982 & $\begin{array}{l}\text { general Tax Amnesty } \\
\text { special program to encourage } \\
\text { repatriation of untaxed assets }\end{array}$ & $\begin{array}{l}19 \text { (only } 2786 \text { participants) } \\
22 \text { (only } 276 \text { participants) }\end{array}$ & $\begin{array}{l}0.007 \\
0.008\end{array}$ \\
\hline France & 1986 & $\begin{array}{l}\text { second special amnesty for assets } \\
\text { held abroad }\end{array}$ & & \\
\hline India & 1981 & $\begin{array}{l}\text { Government bonds designed for } \\
\text { untaxed } \\
\text { Income }\end{array}$ & & \\
\hline India & 1997 & general Tax Amnesty & 2,500 & 8.5 \\
\hline Ireland & 1988 & general Tax Amnesty & $700-750$ & 4.5 \\
\hline Ireland & 1993 & general Tax Amnesty & significantly lower than 1988 & \\
\hline Italy & 1982 & general Tax Amnesty & 100 & 15 \\
\hline Italy & 1984 & Entrepreneurs and self employed & 5,000 & \\
\hline Italy & $2001 / 2002$ & $\begin{array}{l}\text { special program to encourage } \\
\text { repatriation of untaxed assets }\end{array}$ & 1,400 (in Euro) & 0.4 \\
\hline Netherlands & $\begin{array}{l}\text { 1934, 1940, } \\
1945,1955\end{array}$ & $\begin{array}{l}\text { 1955, exemption from penalties and } \\
\text { Interest }\end{array}$ & very good & \\
\hline New Zealand & 1988 & general Tax Amnesty & 18 (good response) & \\
\hline Portugal & $\begin{array}{l}1981,1982 \\
1986,1988\end{array}$ & Limited to income taxation & $40 \%$ of the forecasted amount & \\
\hline Russia & 1993 & $\begin{array}{l}\text { enterprises, organisations, private } \\
\text { entre- } \\
\text { preneurs not liable for any penalties on } \\
\text { unpaid liabilities }\end{array}$ & & \\
\hline Russia & 1996, 1997 & $\begin{array}{l}\text { enterprises and organisations were } \\
\text { allowed } \\
\text { to defer payments on the arrears }\end{array}$ & $\begin{array}{l}1996(1997) \text { negative } \\
\text { (positive) but } \\
\text { insignificant effect on revenues }\end{array}$ & \\
\hline Spain & 1977 & $\begin{array}{l}\text { Exemption from penalty for tax } \\
\text { liabilities settled prior to } 1976\end{array}$ & & \\
\hline
\end{tabular}

Sources: Alm (1998, pp. 5- 6), Alm, Martinez-Vazquez, Wallace (2001), Cassone and Marchese (1995, p. 62), Marchese and Privilegg (1997, p. 403). Feld (2002, p. 7), Hasseldine (1998, p. 307), OECD (1990, p. 90), US Joint Committee on Taxation 1998 (JCS-2-98, P 31ff), and Uchitelle (1989, p. 50-52). 
purpose, which income taxes based on local income.

\section{Indonesia}

Based on UU no 11 year 2016, one of Tax Amnesty purpose is to increase short term revenues, and for the long term revenues are obtained from the taxpayers' obedience by having taxpayers' accurate database.

\section{India}

The purpose of Tax Amnesty is to give chances for tax scammer who haven't reporting and paying their taxes yet. Because of that, the implications of Tax Amnesty are charging ransom and other charging, also fine for unpaid taxes.

\section{Types of Tax Amnesty \\ Indonesia}

Indonesia applied general Tax Amnesty, which including each kind of taxation obligation, either domestically or abroad. Indonesia adheres to nationality principles in implementing their taxation, so each Indonesian citizen, wherever they are should report and paying for their taxes, means the overseas income will be charged with tax. So Indonesia Tax Amnesty will sourced from domestically and overseas wealth declaration, also from abroad repatriation.

\section{India}

Tax Amnesty type that implemented by India is Income Declaration Scheme (IDS), which only including domestic income taxes. The consequences is, all the taxpayers should declared only all their domestic wealth and income.

\section{Time Period}

Tax Amnesty had specific time period and can be done more than once.

\section{Indonesia}

Tax Amnesty in Indonesia had 9 months period, started since July 1, 2016 until March 31,2017 and the forgiven taxes period is until December 31, 2015. Those 9 months period is parted as 3 period, which are July 1 until September 30,2016; the second period started October 1 until December 31, 2016; and the third period, or the last is January 1, until March 31, 2017. Indonesia had been doing Tax Amnesty for many times, in 1964, 1984, 2007, 2015, and 2016.

\section{India}

India Tax Amnesty is done in 4 months, from June 1, 2016 until September 30, 2016; and had been done in several times, in 1951, 1965, 1965, 1965, 1965, 1975, 1981,1986, 1991,1997,2015 and 2016.

\section{Tax Penalties}

Tax Penalties is how much fine or penalty given for Tax Amnesty. Each country will implement different fare based on how much Tax Amnesty is given.

\section{Indonesia}

The partition of Tax Amnesty period followed with different fare charged, those are $2 \%, 3 \%$, and $4 \%$ for domestic wealth repatriation and declaration accordingly. While overseas wealth declaration each charged $4 \%, 6 \%$, and $10 \%$ in order. As comparison, Indonesia highest tax fare for personal is $35 \%$ and company is $25 \%$.

\section{India}

India's Tax Amnesty charged $30 \%$ with additional costs 7,5\% and penalty started from $7,5 \%$ until $45 \%$. As comparison, India's highest tax fare for personal is $35,5 \%$ and company is $30 \%$. (https://id.tradingeconomics. com/india/personal-income-tax-rate,)

\section{Participation Level}

Defined as citizen response or feedback about government solicitation to take part in Tax Amnesty in specific period of times. 
Those citizen responses to take part is mainly determining in the successful rate of Tax Amnesty policy.

\section{Indonesia}

Tax Amnesty is done persuasively and diplomatically, which had been exampled by the president, Joko Widodo by urging the businessmen to have dialogues in any places. The government echoing Tax Amnesty for 9 months in any chances and occasions that enables them to organize seminars or socialization about Tax Amnesty. Those efforts results 400.000 registered taxpayers from total 30 million taxpayers.

\section{India}

India Tax Amnesty is law enforcement and done by India Prime Minister, Narendra Modi. They targeted 700 thousand tax scammer or domestic black money, but in the end the realized Tax Amnesty only results 64.275 taxpayers.

\section{Results of Tax Amnesty}

One of expected short-run results from Tax Amnesty implementation is cash collected from new taxpayers.

\section{Table 3. Overview of Tax Amnesty Implementation Comparison in Indonesia and India*)}

\begin{tabular}{|c|c|c|c|}
\hline NO & DESCRIPTION & INDONESIA & INDIA \\
\hline \multicolumn{4}{|c|}{ Demographics Data } \\
\hline 1 & Total Population 2016 & 257 million people & 1.300 million people \\
\hline 2 & Tax Ratio ( Sept 2015) & $12 \%$ & $17 \%$ \\
\hline 3 & Economic Growth 2016 & $5,02 \%$ & $7,1 \%$ \\
\hline 4 & Country Status & Developing Country & Developing Country \\
\hline 5 & GDP & 861,9 billion USD & 2,074 triliun USD (2015) \\
\hline 6 & GDP per capita & 3.346,49 USD ?(2015) & $1.581,59$ USD \\
\hline 7 & Country Location & Southeast Asia & South Asia \\
\hline \multicolumn{4}{|c|}{ Rules of Tax Amnesty Implementation } \\
\hline 1 & Time Period & $1 / 7 / 2016$ until $31 / 12 / 2017$ & $1 / 6 / 2016$ until $30 / 9 / 2016$ \\
\hline 2 & Ransom Scale & until 10\% & $30 \%$ until $45 \%$ \\
\hline 3 & Approach & Persuasive, diplomatic & Law enforcement \\
\hline 4 & Types of amnesty & $\begin{array}{l}\text { General, any kind of taxes until } \\
31 / 122015\end{array}$ & $\begin{array}{l}\text { Specific, domestic tax fraud (black } \\
\text { money) }\end{array}$ \\
\hline 5 & Company tax fare & until $25 \%$ & $34,61 \%$ \\
\hline \multicolumn{4}{|c|}{ Results of Tax Amnesty } \\
\hline 1 & Targeted Income & $165 \mathrm{~T}$ & $58,5 \mathrm{~T}$ ( $4.5 \mathrm{M}$ US $\$)$ \\
\hline 2 & Domestic Declaration & $3.700 \mathrm{~T}($ target $: 4.000 \mathrm{~T})$ & $123 \mathrm{~T}(9,5 \mathrm{M}$ US $\$)$ \\
\hline 3 & Repatriation & $147 \mathrm{~T}$ (target: $1,000 \mathrm{~T})$ & - (domestic only) \\
\hline 4 & Revenues & $135 \mathrm{~T}$ & $57 \mathrm{~T}$ \\
\hline 5 & $\begin{array}{l}\text { Targeted Participants / } \\
\text { Taxpavers }\end{array}$ & 30 million taxpayers & 700.000 taxpayers \\
\hline 6 & Participated taxpayers & 400.000 taxpayers $(1,3 \%)$ & 64.275 taxpayers ( $9 \%$ ) \\
\hline 7 & $\begin{array}{l}\text { Frequents of Tax } \\
\text { Amnesty }\end{array}$ & $5 \mathrm{x}$ & $12 \mathrm{x}$ \\
\hline
\end{tabular}

Source : processed data

*)

- http://bisniskeuangan.kompas.com/read/2016/10/03/070400926/india.ternyata.juga.terapkan.tax. amnesty.

- https://id.wikipedia.org/wiki/Daftar_negara_menurut_jumlah_penduduk

- https://id.tradingeconomics.com/india/personal-income-tax-rate 


\section{Indonesia}

By persuasively and embracing all classes because of its objectives, Indonesia Tax Amnesty not only collecting cash, but also expanding their tax database, even until the end of Tax Amnesty period, the collected ransom attains 135 trillion IDR, targeted income 165 trillion IDR, and declared domestic wealth 3700 trillion IDR.

\section{India}

India Tax Amnesty is done twelve times, while the revenue from ransom is 57 trillion IDR and the declared wealth is 123 trillion IDR. Those amounts are sum of only domestic wealth declaration in twelfth Tax Amnesty.

Based on those Tax Amnesty, both in India or Indonesia, can be concluded as (Table 3).

\section{Summary}

Some important things that can be summarized from Indonesia and India Tax Amnesty are :

- Both Indonesia or India has been doing Tax Amnesty for several times, the difference is Indonesia done it 4 times, while India twelve times
- While implementing Tax Amnesty, Indonesia prioritizing solicitation and diplomatic, India is law enforcement

- Both Indonesia and India have the same purpose of Tax Amnesty, that is recollecting tax receivables or tax debt from taxpayers. But Indonesia also emphasizing to obtain more accurate taxpayers' database

- Indonesia Tax Amnesty type is general, while India is specific, limited to domestic taxpayers.

- Indonesia obtained ransom is 135 trillion IDR, bigger than India which only 57 trillion IDR with comparison of wealth declared is 3700 trillion IDR and 123 trillion IDR, even with lower amnesties in Indonesia, which is up to $10 \%$ while in India up to $45 \%$.

- Participant of Indonesia Tax Amnesty is 400.000 taxpayers while in India only 64.275 taxpayers

At the end, it can be concluded that seen from the number of taxpayers participated in Tax Amnesty and the obtained revenues, Indonesia's Tax Amnesty is more successful than India. It can be caused of longer time period, lower ransom fares in amnesty, and the type of amnesty that more general and common.

\section{References}

Alm, James; Michael McKee and William Beck. 1990. Amazing Grace : Tax Amnesties and Compliance, National Tax Journal. 43: 23-37.

Baer Katrine, 2008, Tax Amnesty: Theory, thrends and Some Alternative, International Moneterry fund, washington DC. ISBN : 978-1-58906-736-3 mm

Eric Le Borgne. 2006 , Economic and Political Determinants of Tax Amnesties in the U.S. States, IMF Working Paper, Fiskal Affairs Department, Authorized for distribution by Michael Keen

Herman B. Leonard, Richard J. Zeckhauser, 1987, Tax Policy and the Economy, Volume 1 the National Bureau of Economic Research ISBN: 0-262-19263-2

Kluwer Wolters, 2011, Tax Amnesties, Kluwer Law International, The Netherlands. ISBN 978-90-411-3364-9 
Prastowo Yustinus, 2016, Perpajakan Indonesia : Bergotong Royong Menuju Kesejahteraan, Center for Indonesia Taxation Analysis, Smart Wikan Profesional Surabaya

https://www.halomoney.co.id/blog/infografik-tarif-pajak-penghasilan-di-dunia, Diakses 6 Juli 2017

https://id.wikipedia.org/wiki/Daftar_negara_menurut_jumlah_penduduk. Diakses 6 Juli 2017

https://id.tradingeconomics.com/india/personal-income-tax-rate. Diakses 6 Juli 2017

http://bisniskeuangan.kompas.com/read/2016/10/03/070400926/india.ternyata.juga. terapkan.tax.amnesty.bagaimana.hasilnya. Diakese 6 Juli 2017

Undang-undang Republik Indonesia 11 tahun 2016, Tentang Tax Amnesty, Lembaran Negara Republik Indonesia tahun 2016 nomor 5899 
